\title{
What do we need for a Second Republic? High Energy Democracy and a Triple Movement
}

\section{Mary P. Murphy}

\section{(2) OpenEdition \\ 12 Journals}

\section{Electronic version}

URL: http://journals.openedition.org/etudesirlandaises/4969

DOI: 10.4000/etudesirlandaises.4969

ISSN: 2259-8863

\section{Publisher}

Presses universitaires de Rennes

\section{Printed version}

Date of publication: 30 November 2016

Number of pages: $33-50$

ISBN: 978-2-7535-5358-3

ISSN: 0183-973X

\section{Electronic reference}

Mary P. Murphy, "What do we need for a Second Republic? High Energy Democracy and a Triple Movement », Etudes irlandaises [Online], 41-2 | 2016, Online since 30 November 2018, connection on 20 April 2019. URL : http://journals.openedition.org/etudesirlandaises/4969; DOI : 10.4000/ etudesirlandaises.4969 


\title{
What Do We Need for a Second Republic? High Energy Democracy and a Triple Movement
}

\author{
Mary P. MuRphy \\ Maynooth University
}

Abstract

This article discusses the prospects of Ireland emerging from crisis renewed and reformed as a second republic. Evidence from opinion polls and surveys confirms Irish citizens value key republican principles of equality, rights and fair distribution; however, trust in politics, government and non-government organisations is low and the 2016 general election confirmed the absence of leadership to create political momentum around such values. The answer to the question of what is needed to generate a new politics or a high energy democracy lies in understanding how the crisis has impacted on values and attitudes towards key leadership institutions and how it has changed Irish political and civil society. Examining the relationship and linkages between the two allows some assessment of Irish political and civil society's capacity for a values-led discourse that could promote a transformative-type change. We identify the absence of effective framing, a necessary prerequisite for effective linkage and mobilisation. What is required for new politics is an Irish triple movement which incorporates gender and social reproduction, as well as environmental and traditional distributional concerns about income equality and public services. Such framing offers potential to mobilise across a wide range of actors and create a livelier battleground in which the interests of a much wider section of the population can find expression, create new alliances, reshape power relations and, over time, create a second republic.

Mots clés: Irlande, société civile, renouvellement politique, triple mouvement, cadrage idéologique (framing).

\section{Résumé}

Le présent article examine et évalue la perspective d'un renouvellement politique en Irlande qui pourrait prendre la forme d'une seconde république à la suite de la crise. Enquêtes et sondages confirment que les citoyens irlandais sont attachés aux principes-clés républicains d'égalité, de respect des droits et de répartition équitable; cependant, la confiance dans la politique, dans le gouvernement et dans les organisations non-gouvernementales est faible, et les élections législatives de 2016 ont confirmé l'absence d'une direction structurée pouvant créer un effet d'entraînement politique autour de telles valeurs. Pour identifier les éléments nécessaires à la production d'un nouvel environnement politique et d'une démocratie dynamique, il faut d'abord comprendre l'impact que la crise a eu sur les valeurs et les attitudes vis-à-vis des principales institutions politiques et comment elle a transformé la société politique et civile irlandaise. L'analyse des relations et interconnections entre les deux permet d'évaluer dans une certaine mesure la capacité de la société politique et civile irlandaise à développer un discours fondé sur des valeurs et qui serait de nature à promouvoir un processus de changement profond. Parmi les facteurs de transformation manquants, on peut identifier en particu- 
lier l'absence d'un cadrage ou discours cadre (framing) efficace, pré-condition nécessaire à une mise en réseau et une véritable mobilisation. Pour rendre possible un renouvellement politique, il faut pouvoir imaginer en Irlande un triple mouvement prenant en compte la problématique de la reproduction sociale et genrée, celle de l'environnement et celle, plus traditionnelle, de la répartition socioéconomique, autour de l'égalité de revenus et des services publics. Un tel cadrage (framing) pourrait mobiliser un large éventail d'acteurs et ouvrir un champ de discussion politique plus dynamique, au sein duquel les intérêts d'une bien plus large part de la population pourraient trouver leur expression, dans un mouvement propice à la création de nouvelles alliances, à la reconfiguration des relations de pouvoir et, à terme, à la mise en place d'une seconde république.

Keywords: Ireland, civil society, new politics, triple movement, framing

\section{圈 Introduction}

Reflecting on the outcome of the 2011 Irish general election (GE), Peadar Kirby and I discussed the prospects of Ireland emerging from crisis renewed and reformed as a second republic ${ }^{1}$. We mapped Irish political and civil society's capacity for a values-led discourse that could promote a transformative type of change. Five years later, reflecting on the outcome of the 2016 Irish GE, this article revisits the challenge of achieving the type of fundamental political, economic and social renewal encapsulated in the idea of a "second republic". It is clear that the 2011 "pencil revolution" and rejection of FF as the dominant political power actor did not transform the direction of the Irish republic, but it did signal "the beginning of the beginning". It remains to be seen whether the 2016 GE represents a watershed in realigning politics away from civil war or tribal politics and towards more traditional European socio-economic cleavages.

Ireland survived crisis without significant change, but with a path-dependent intensification of the neoliberal model $^{2}$. We see increased levels of privatisation and managerialism and continuous loyalty to a low tax regime and foreign direct investment-led industrial policy ${ }^{3}$. We also see regression in key republican outcomes, with child poverty doubled from 6\%-12\%, increases in the gender pay gap from $12.6 \%$ to $14.4 \%$, deprivation of up to $63 \%$ for lone parents and poor

1. Peadar Kirby and Mary P Murphy, Towards a Second Republic - Irish Politics after the Celtic Tiger, London, Pluto, 2011.

2. Mary P. Murphy, "Ireland: Celtic Tiger in Austerity - Explaining Irish Path Dependency: Social welfare and the ethics of austerity in Europe - justice, ideology and equality", Journal of Contemporary European Studies, vol. 22, $\mathrm{n}^{\circ}$ 2, April 2014, p. 132-142; Colin Coulter and Angela Nagle (eds), Ireland Under Austerity, Neoliberal Crisis, Neoliberal Solutions, Manchester, Manchester University Press, 2015; Julien Mercille and Enda Murphy, Deepening Neoliberalism, Austerity, and Crisis Europe's Treasure Ireland, Basingstoke, Palgrave, 2015.

3. Mary P. Murphy and Fiona Dukelow (eds), The Irish Welfare State in the 21st Century, Challenges and Changes, Basingstoke, Palgrave Macmillan, 2016. 
progress in addressing many forms of social and economic exclusion and spatial inequality ${ }^{4}$. Domestically, little has happened to foster a contestatory and participative citizenship, to separate power or make elites transparent or accountable 5 . Likewise, international power arrangements have evolved to undermine national autonomy and sovereignty.

In 2011, Kirby and Murphy argued "To date one key barrier to transformation is the lack of significant demand from below and an apparently low level of ambition for change in society, without which change is unlikely to emerge from above $e^{6 "}$. In early 2016, it is not yet clear that a substantial proportion of Irish people will mobilise around shared progressive republican values. Over the crisis period, various movements and campaigns emerged to popularise such values but, other than the Right2Water movement, none had a significant impact in influencing public discourse, and the framing of the Right 2 Water campaign did not champion republican values. This article is concerned with recent political and social change in Ireland and the type of political, structural and funding challenges Irish political and civil society faces in the context of fallout from austerity. It reviews the restructuring of power relations in the context of an increasingly fractured political society and offers some assessment of the impact civil society might have in shaping post-crisis and post-2016 discourse in Ireland. The first section reflects on what recent European Social Survey, Eurobarometer, domestic polls and political narratives tell us about how citizens value solidarity, equality and trust in state institutions, key requirements in any republic. The next section reviews the present state of Irish political society as it emerged from $2016 \mathrm{GE}$. The third section reviews different dimensions of post-crisis Irish civil society. The final section draws on lessons from elsewhere to interrogate the links between Irish political and civil society and to assess prospects of momentum towards a political project based on equality - a second republic.

\section{圈 Values and Narratives}

This section reviews whether Irish values are consistent with those we might expect to find in a republic. In April 2015 a Red C poll ${ }^{7}$ commissioned by the Irish Human and Equality Rights Commission (IHREC) found mixed results about awareness of equality and human rights in Ireland. Overall, people express

\footnotetext{
4. Irish Human Rights and Equality Commission, IHREC Submission to UNECSR, Dublin, IHREC, 2015. P. Kirby and M.P. Murphy, Towards a Second Republic, op. cit., Chapter 10.

5. David Farrell (UCD), Eoin O'Malley (DCU), Theresa Reidy (UCC) and Jane Suiter (DCU), "Smaointe: Assessing the parties' reform proposals", taken up on the Irish Politics Forum ("A PSAI blog for discussion of politics, policy and political reform"), 24 February 2016, [http://politicalreform.ie/2016/02/24/smaointe-assessingthe-parties-reform-proposals/2016.

6. P. Kirby and M.P. Murphy, Towards a Second Republic, op. cit., Chapter 10.

7. Irish Human Rights and Equality Commission, RED C Poll, April 2015, [http://www.ihrec.ie/news/2015/07/30/].
} 
positive views on human rights and equality issues with some variation from issue to issue and with young people and women expressing stronger support. The poll found almost universal (96-93\%) endorsement of the general importance of equality and human rights and support for regulating to create a fairer, more equal society. It seems that Irish people believe that no matter who you are or where you come from, you should be treated equally. They also care deeply about making Ireland a fairer place in which to live, $79 \%$ per cent believing that Ireland has more to do in protecting human rights and equality. A Red C poll after the May 2015 Marriage Equality referendum recorded an increase in the proportion viewing Ireland as a leader in Europe on equality and human rights. This affirms leadership, public narratives and mobilisation are important in building support for and pride in such values. TASC's ${ }^{8}$ (a think tank for action on social change) 2014 annual "solidarity factor" poll by Behaviour and Attitudes found over $80 \%$ polled want Ireland to be more equal and that $50 \%$ of the Irish people - up from $35 \%$ in 2010 - are willing to pay higher taxes for guaranteed high quality public services. $80 \%$ believe that income in Ireland is unfairly distributed and $90 \%$ are in favour of either increasing the minimum wage and/or establishing a maximum wage to reduce the gap between high and low earners. TASC attributes increased awareness of the value of public services to citizens' practical reflection on what was lost in cutbacks. Exit polls from the 2016 general election confirm public support for increased taxes to boost investment in public services ${ }^{9}$. Garry's ${ }^{10}$ analysis of the RTE GE 2016 exit poll confirmed that the average position of the Irish voter is 5.9 on the economic leftist side of the taxes v. public services debate. The same poll found significant variations in attitudes to inequality, but the majority agreed that the government "should act to reduce differences in income and wealth". Likewise, most voters were on the liberal side of the question of abortion. These findings confirm that Irish citizens consistently identify with republican values.

Economic crisis in the Eurozone is associated with a significant loss in citizens' trust in their national parliament in Ireland, Spain, Portugal, and Greece ${ }^{11}$. O'Sullivan et al. ${ }^{12}$ used European Social Survey data to examine political legitimacy in Ireland over the economic crisis and found trust in political institutions and satis-

8. TASC, [http://www.tasc.ie/news/2014/12/15/1-in-2-irish-people-willing-to-pay-higher-taxes].

9. Election 2016: Irish Times exit poll, 27 February 2016, [http://www.irishtimes.com/news/politics/election2016-irish-times-exit-poll-shows-coalition-well-short-of-overall-majority-1.2550489].

10. John Garry, "Analysis of ideological positions in RTE exit poll", RTE News, 27 February 2016, [http://www. rte.ie/news/election-2016/2016/0227/771246-ideological-voters/2016.

11. Eurobarometer Standard Eurobarometer 81, Public Opinion in the EU 2014, Spring 2014 [http://ec.europa.eul public_opinion/archiveslebleb81/eb81_publ_en.pdf].

12. Siobhan O'Sullivan et al., Political Legitimacy in Ireland During Economic Crisis: Insights from the European Social Survey, Irish Political Studies, Vol. 29, nº 4, p 547-572, 2014. 
faction with government declined since 2008. While satisfaction with government increased since the 2011 election, it has subsequently declined. Figure 1 from the most recent Eurobarometer surveys ${ }^{13}$ highlights the acute lack of trust in political parties with at one time up to $80 \%$ distrusting more than trusting political parties, a reality echoed in the anti-establishment rhetoric and success of independent candidates in GE 2016, particularly in rural and working class areas.

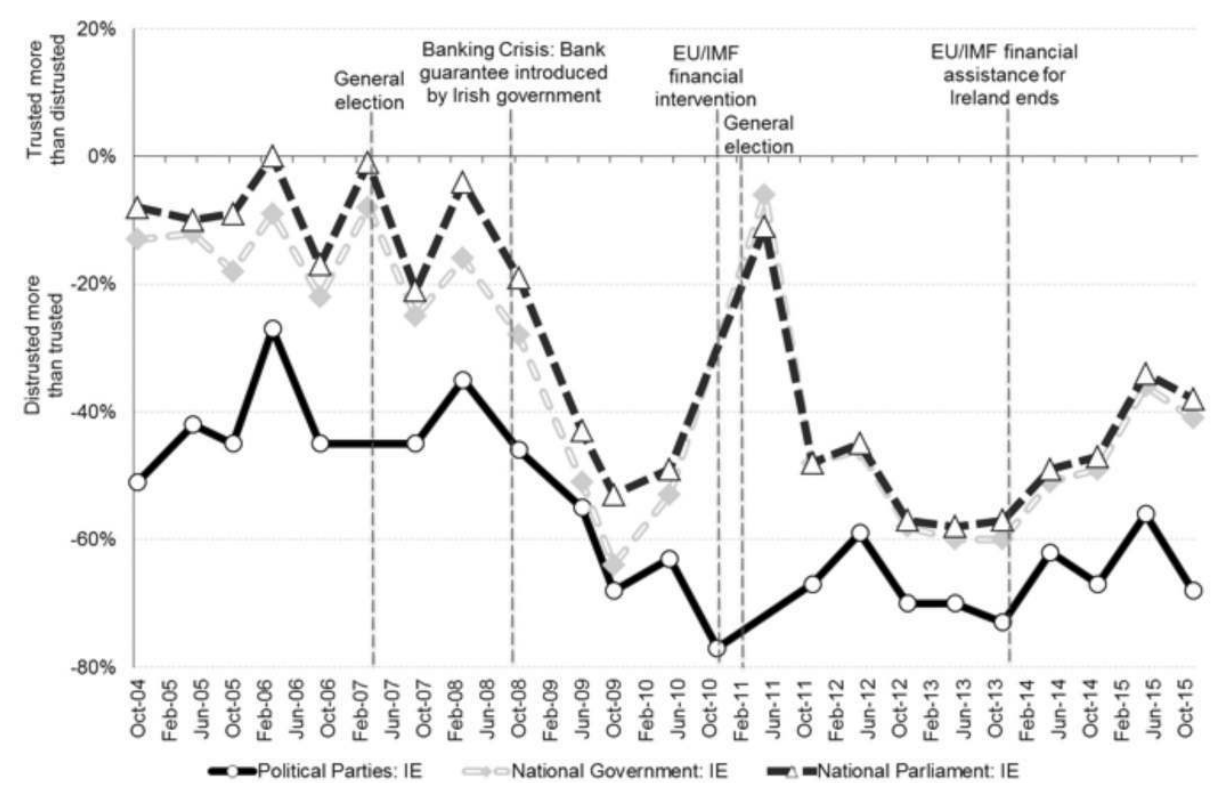

Figure 1: Index of trust in national political institutions in Ireland 2004-2015 (\%) (Source of data: EB62-EB84 [See Eurobarometer Report 84, Figure 2, p. 5]).

Despite a nascent economic recovery, trust in 2015 remains similar to levels at the height of the recession. The 2015 Edelman Trust Barometer ${ }^{14}$ ranked Ireland second from bottom of 27 countries for levels of trust and found that while government experienced a modest recovery in trust over 12 months, trust in Irish NGOs, business and media declined in the same period. The lack of trust is evident in Hearne's ${ }^{15}$ survey of 2,500 Irish water activists. 54\% of respondents were new entrants to protest politics and, while reasons for protest varied, lack of trust was a key factor in protesters shifting towards protest-oriented political

13. Quinlan S. Eurobarometer 84: Report on Ireland Dublin : European Commission Representation in Ireland. 2016 [http:/lec.europa.eu/public_opinion/archives/ebleb80/eb80_ie_ie_nat.pdf]. Reidy T Understanding Election 2016: Perspectives from Eurobarometer 84, 2 March 2016 [https://politicalreform.ie/2016/03/12/understanding-election-2016-perspectives-from-eurobarometer-84/].

14. Edelman Trust Barometer, [http://www.edelman.ieledelman-trust-barometer-2015-2/].

15. Rory Hearne, The Irish water war, austerity and the "Risen people", Maynooth, NIRSA, 2015. 
tactics (including greater use of social media) and their support for extending such protest to other issues as well as openness to new political parties. Pre-crisis, Irish citizens had some sense of power or political efficacy and felt able to influence the political system ${ }^{16}$. Polls since do not necessarily show more "powerlessness", but show a clear mistrust in politics and political parties. The Irish, along with most Europeans, still have a broad notion of democracy and attach importance to key procedural aspects of a liberal electoral democracy, such as free and fair elections and equality before the law, as well as the social and direct democracy dimensions of democracy which enable citizens participate directly in decision-making ${ }^{17}$. This helps explain demand for a "new politics" even as the European (and international) political environment stifles democracy and change.

Who might citizens trust as leaders, and who might people listen to? The crisis illustrated how government, as part of a strong ruling elite, very effectively manufactured consent and maintained hegemonic power ${ }^{18}$. Edelman's survey measured trust across various media sources, with traditional media (newspapers, radio and television) the most trusted source of information in Ireland and academics or industry experts the most trusted spokespeople at 78\%, with CEOs and Government officials the least trusted, at 34\% and 33\% respectively. Mercille's ${ }^{19}$ analysis of 431 editorials and opinion articles discussing fiscal consolidation between 2008 and 2012 in three leading Irish newspapers (Irish Times, Sunday Independent, Irish Independent) found little in terms of alternatives to austerity and even less in terms of anti-capitalist narrative. Murphy ${ }^{20}$ examined how ideas, institutions and actors interacted throughout the crisis to either maintain or intensify policy continuity or to create path-shaping moments of change, and identified three austerity-related discourses: reform, transformative and revolutionary narratives. The dominance of the fiscal consolidation reform narrative in mainstream media reflects the successful framing activities of the dominant political and economic coalition who proactively reshaped institutions to centralise power and continue to direct the nature of political discourse to maintain an already strong path-dependence in the Irish economic and social model.

Those presenting alternatives are protest-oriented and sometimes uncertain, or differ with each other about how to define core problems or potential policy solutions. Harvey ${ }^{21}$ shows how key institutional shifts in funding, regulation and

16. John Garry, Niamh Hardiman and Diane Payne (eds), Irish Social and Political Attitudes, Liverpool, Liverpool University Press, 2006.

17. European Social Survey, Top Line Results Issue 4 Europeans' Understandings and Evaluations of Democracy, EC, ESS, 2012.

18. Mary P. Murphy, "Ireland: Celtic Tiger in Austerity", Journal of Contemporary European Studies, vol. 22, n 2, April 2014, p. 132-142.

19. Julien Mercille, "The role of the media in fiscal consolidation programmes: the case of Ireland", Cambridge Journal of Economics online, 11 December 2013, p. 1-20.

20. M.P. Murphy, "Ireland: Celtic Tiger in Austerity", op. cit.

21. Brian Harvey, Are we paying for that?, Dublin, Advocacy Coalition, 2014. 
policy implementation centralised power and narrowed democratic representative and participative space. This weakened non-elite political coalitions and their capacity to build alternative narratives. Despite significant degrees of social dislocation, opposing political coalitions have been relatively weak and not yet sufficiently articulated, nor have they won support for any alternative or been able to contest dominant narratives. The challenge remains building capacity and developing narratives to mobilise different groups in support of alternatives encapsulated in the concept of a second republic. This question is particularly relevant in this decade of commemoration which itself offers opportunities to both reflect on what kind of society and economy Irish people want and to translate such reflection into meaningful political mobilisation.

In summary overall we see core values of equality and human rights intact and even strengthened over crisis but see significant mistrust in political and social institutions including NGOs and traditional media. We also see emerging forms of political participation and social media and the opportunity presented in a decade of commemoration. But how are citizens reacting to engaging with new and emerging forms of politics and who might they trust as leaders? The next section sheds some light on these questions by reviewing Irish political society and assessing its capacity to generate or reflect demand for a second republic.

\section{圈 Looking forward - mapping political society}

What political possibilities opened up in the 2016 general election? Has Ireland inched closer to a second republic? The Fine Gael (FG) /Labour Party (LP) coalition government (in power from 2011- 2016) had previously used rhetoric about and implied a vision for a second republic and the 2011 Programme for Government committed to a constitutional convention to review and renew the Irish Constitution. This potential for political reform proved somewhat of a damp squib as government proved themselves unambitious about the scale of reform they were willing to engage in or able to implement. Sceptical citizens demonstrated how little they trusted the government's reform agenda when they rejected three political reform referenda. On distributional issues, government budgets were largely regressive and were hardly informed by republican principles or values ${ }^{22}$.

Pro-business FG, associated with the mantra "the best little country in the world to do business in", was eager to promote a lightly regulated and low-tax competitive state, privatisation, and a more conditional approach to social policy. FG's association with corruption ${ }^{23}$, numerous scandals (SiteServ), close relation-

22. IHREC, IHREC Submission to UNECSR, op. cit.

23. Elaine Byrne, The Crooked Harp, Manchester, Manchester University Press, 2012. 
ships with business actors such as Denis O'Brien and political appointments ${ }^{24}$ also cost the party; their preoccupation with the economy at the expense of society led to a resounding electoral defeat, losing 26 of their 77 seats.

The junior 2011-2016 coalition partner, the LP, still espouses rhetorical ambition for substantive outcomes. The LP influenced government policy, generating some equality oriented policy outcomes including the marriage equality referendum, protection of life in pregnancy bill, and the reversal of minimum wage cuts. However, it was unable to direct overall government policy away from a low tax and low social expenditure framework and was itself directly implicated in cuts that hurt vulnerable groups. The LP tactically entered the 2016 GE willing to reenter government as an even more minor coalition partner and without championing serious reform. The electorate resoundingly rejected the LP who lost 25 of its 32 remaining seats. The LP had experienced five parliamentary resignations over the 2011-2015 period, one of whom, Roisin Shortall, went on to co-lead a new party, the Social Democrats, who stood on a pro-tax public services and political reform platform and returned their existing 3 seats in the $2016 \mathrm{GE}$.

The largest outgoing opposition party, FF, regard themselves as a republican party and entered GE 2016 with a "fairness" rhetoric but with a policy platform consistent with a neoliberal political economy model. This rhetoric aligned with strong local constituency work to generate an expected political revival where they doubled their seats to 44 in GE 2016. A number of liberal but economically centre-right independents, rather than developing a political party, have brokered an "Independent Alliance" under the leadership of the centre-right Shane Ross and won 6 seats in the 2016 GE. Sinn Féin, a nationalist republican party with origins in the Northern Ireland conflict and aligned to the physical force republican movement, continued its incremental growth in the Republic positioned as a centre left party; it increased from 14 to 23 seats. The radical United Left Alliance who entered the 2011 parliament with seven seats subsequently fell into disarray with two individual members leaving to become independents and the Socialist Party splitting from ULA (and subsequently experiencing its own internal splits). A subsequent reconciliation saw the Socialist Party (Anti Austerity Alliance) and Socialist Workers' Party (People Before Profit) registering as a political party AAA-PBP and winning 6 seats in the 2016 GE $^{25}$. A mixture of centre-right gene pool, left and single-issue independents won 18 seats, 5 of whom have grouped into a centre-right rural alliance.

24. "Timeline: the Siteserv controversy - What's the story behind the issue?", Irish Times, 29 May 2015, [http:// www.irishtimes.com/business/financial-services/timeline-the-siteserv-controversy-1.2230748].

25. Sarah Bardon, "Irish Times Anti Austerity Alliance and People before Profit to launch new party", Irish Times, 16 September 2015, [http://www.irishtimes.com/news/politics/anti-austerity-alliance-and-people-before-profit-tolaunch-new-party-1.2353674]. 
What Do We Need for a Second Republic? High Energy Democracy and a Triple Movement

\begin{tabular}{|l|c|c|}
\hline \multicolumn{1}{|c|}{ Political Party } & Seats 2011 & Seats 2016 \\
\hline Fine Gael & 77 & 50 \\
\hline Fianna Fail & 21 & 73 \\
\hline Labour Party & 37 & 23 \\
\hline Sinn Fein & 14 & 0 \\
\hline United Left Alliance (2011) & 7 & 6 \\
\hline AAA PBP (2016) & 0 & 3 \\
\hline Social Democrats & 0 & 2 \\
\hline Green Party & 0 & 6 \\
\hline Independent Alliance & 0 & 18 \\
\hline Independents & 14 & 7 \\
\hline
\end{tabular}

Table 1: Outcome of 2016 General Election compared to 2011 General Election, political parties and Independents

The GE 2016 Seanad vocational panel elections returned 11 FG seats, 14 FF seats, 7 SF seats, 4 LP seats, and 1 GP seat alongside 5 seats for "Independents and Others" who had a notably strategic election ${ }^{26}$. The Trinity and NUI constituency returned a gender balance with two conservative males, one progressive male and three progressive women. The elected Seanad is now more gender balanced (28.6\% of the 49 candidates) and Taoiseach's nominees may stretch the gender balance to $30 \%$, the tipping point thought necessary for cultural change. The minority Fine Gael government with a maximum of 24 of out 60 seats will not command an overall majority in the new Seanad based on their current seat levels, but it is still the case that like the lower house, the majority of senators are from the two centre right parties (FF and FG).

At the time of writing, FG had their return as a minority government with a three-year "supply and confidence" deal with FF. It remains to be seen how long this arrangement will last and when the next GE will be. The question for this discussion is whether the next election will contribute to a further dissolution of old politics and open up potential for a "new politics" capable of generating demand for a second republic. In 2011 Kirby and Murphy argued that leftwing parties leading a left-led government were more likely to promote a republic based on equality and sustainability. Opinions diverge about the degree to which GE 2016 represented an electoral advance for the Irish left. Hearne ${ }^{27}$ and

26. Adrian Kavanagh, "Seanad Elections 2016, a final overview", posted 28 April 2016, [https://adriankavanaghelections.org/2016/04/28/seanad-elections-2016-a-final-overview/].

27. Rory Hearne, "Electorate want a fairer society", Irish Examiner, 29 February 2016, [http://www.irishexaminer. 
O'Toole 28 argue there was a seismic shift towards social democratic politics, but Storey ${ }^{29}$ opines that "sadly, we didn't vote for a fairer Ireland", rather "'all over the place' is a better description of the Irish political landscape than a claimed social-democratic majority". Smyth ${ }^{30}$ observes that the combined left vote of $35 \%$ hardly shifted from the 2011 combined left vote of $33 \%{ }^{31}$, he observes not "realignment towards the left" but "a realignment of the left" away from LP and towards SF, left independents and the radical left.

Debate about the future of the Irish left is made more difficult by a lack of consensus about who is on the left, with the Socialist Party questioning both LP and SF aspirations to be left parties and with GE 2016 marked by significant hostility towards both LP and SF from AAA-BPB ${ }^{32}$. LP choices in government and what Browne ${ }^{33}$ calls the myopic tactics of more radical left parties have contributed to the failure to build a coherent united opposition capable of capitalising on electoral dissatisfaction and demand for a new politics. Mullally ${ }^{34}$ suggests this absence of headline alternatives leaves citizens with little option but to retreat to local constituency politics and independent candidates.

Smyth concludes left unity is a pipe dream. In 2011 Kirby and I argued "it would be naïve to underestimate the degree of challenge in arriving at a realignment of the Irish left ${ }^{35}$ ". In exploring this possibility, Ó Broin ${ }^{36}$ (now a Sinn Féin TD) identified the difficulty of realigning the different political strategies of the three left parties, with LP following an institutional tradition, the various bodies that comprise AAA/PBP following a mobilisation tradition and Sinn Féin (SF) emerging into an institutional strategy from a long history as an adjunct to a physical force republican movement. Distinctions can also be made among these parties between more reformist politics with a government-oriented policy agenda (LP and SF), and those with more radical oppositional strategies (AAA/PBP). These differences make it difficult to develop and present a credible left alternative to the electorate. Such challenges should not be underestimated, differences in both analysis of the problems and positions adopted through tactical opportu-

com/election2016/election2016-news-and-analysis/electorate-want-a-fairer-equal-society-with-another-seismicshift-in-irish-politics-384614.html].

28. Fintan O’Toole, “The winner of Election 2016 is social democracy", Irish Times, 29 February 2016, [http:// www.irishtimes.com/opinion/the-winner-of-election-2016-is-social-democracy-1.2552917].

29. Andy Storey, "Sadly we didn't vote for a fairer Ireland”, Dublin Inquirer, 1 March 2016, [http://dublininquirer. com/2016/03/01/andy-sadly-we-didnt-vote-for-a-fairer-ireland/].

30. Patrick Smyth, "Left unity still a pipe dream”, Irish Times, 29 February 2016, p. 20.

31. Smyth calculates 53 seats, estimating one third of independents as "left". Ibid.

32. Vincent Browne, "Coalition of the right the price of left myopic stunts", Irish Times, 29 February 2016, p. 20.

33. Ibid.

34. Una Mullally, “Absence of Alternatives”, Irish Times, 1 March 2016.

35. Peadar Kirby and Mary P. Murphy, Towards a Second Republic,, op. cit., Chapter 10.

36. Eoin Ó Brion, "The Future of the Irish Left" paper to session "Political Change and People Power", Left Unity Conference, Gresham Hotel, 5 February 2011. 
nism can widen the gap between different left party positions on issues like service charges. In Ó Broin's description of the Irish left he sees the hard left wing shouting from the side lines and the social democratic wing acting as a mud guard for the centre ${ }^{37}$. He argues,

the reformist left led by Labour and SIPTU have always set their sights too low, overwhelmed by their lack of political strength they were never able to raise their horizons beyond mitigating the worst effects of centre right governments, while the revolutionary left, led by an alphabet soup of Leninist grouplets, has never been able to lift itself out of the comfort zone of pure opposition and slogan based politics and despite the important role they play in many mobilisations their impossibilism has led to their marginalisation ${ }^{38}$.

Smyth is dismal about the prospects of post-GE 2016 left co-operation, arguing that "if anything they are less likely to co-operate, ... are more bitterly divided personally and politically, and are inveterate splitters and expellers of dissent ${ }^{39}$ ". Some had put energy into new left alignment through the Right to Change movement which emerged from the 2014 Right 2 Water campaign to provide a coherent platform for change, mobilising over 100 GE 2016 candidates behind a set of policy principles, and interacting with international political and civil society alliances including Podemos, Syriza, and trade unions at European level. However, post-GE 2016 Right to Change proved to have little subsequent traction; having found themselves outflanked by political party manoeuvring the participating trade unions are reviewing their involvement.

The Polling Indicator ${ }^{40}$ display of party support from 2011-2016 demonstrates significant volatility and fragmentation; this continues post-GE 2016. From an international perspective, it is striking that one of the consequences of the on-going political and economic "crisis" has been the rise of radical/extreme right-wing parties (and in some countries a relative polarisation of the political scene, with the parallel rise of a radical left). Ireland experienced volatility and fragmentation but less extreme right or left populism than in some European states. One factor that differentiates Ireland from other European states is the Irish Proportional Representational Single Transferable Vote electoral system which facilitates election of local independent individual candidates in 40 local constituencies. These candidates to some degree became the focus for the electo-

37. Eoin Ó Broin, “The rights easy ride stops now”, Sunday Business Post, 21 June 2015, p. 15.

38. Ibid.

39. P. Smyth, "Left unity still a pipe dream", art. cit.

40. Tom Louwerse, "Irish Polling Indicator: Government parties bounce back a bit", Irish Politics Forum ("A PSAI blog”), 27 March 2015, [http://politicalreform.ie/2015/03/27/irish-polling-indicator-government-parties-bounceback-a-bit]. 
rate allowing them to express dissatisfaction with political parties and articulate local concerns ${ }^{41}$. The ease with which local individuals can successfully compete in national level elections can make alternative party formation less likely. This also militates against growth in populist parties. This might also partially explain the absence of a new party, modelled on the Spanish Podemos movement, that Hearne ${ }^{42}$ argued could be fuelled by the type of community activism behind the Right to Water campaign.

What might we conclude? The $2016 \mathrm{GE}$ outcome suggests a societal rejection of the economic narrative in favour of one that privileges fairness and society; however it is also the case that the deep fragmentation of the left and increased presence of independents means a persistent lack of coherent political alternatives for citizens to demonstrate these values. Given that political society is not offering coherent alternatives, the next section explores Irish civil society and its potential to offer an alternative basis for organising.

\section{Looking forward - mapping civil society}

What of Irish civil society and its potential contribution towards the evolution of a second republic? Edwards s ${ }^{43}$ somewhat optimistic vision of civil society is of collective, creative and values-based action capable of being a counterweight to individualism, an antidote to cynicism and a balance to both state and market. However, Irish civil society is broad-ranging, with much of it organised around voluntary service, charities and sporting activity and imbued with various political ideologies, not all of which are progressive or transformative. Some are neutral about or compatible with a neoliberal model and so are consistent with and reinforce elite common sense or hegemonic neoliberal narratives. Others mobilising around change work through progressive think tanks, trade unions and $\mathrm{NGOs}^{44}$ to pursue social democratic agendas that are progressive but may not stretch to significant transformation nor promote a counter-hegemonic project. Others including ecological movements and groups give reality to ecological values which

41. The scale of defeat of FF in 2011 opened up significant possibilities in the political landscape. Despite significant entry barriers, the 2011 General Election saw the emergence of political parties such as Democracy Now, New Vision (an association of independent candidates) and Fís Nua (a registered political party), none had any electoral impact. In GE 2016 Social Democrats, Independent Alliance and AAA/PBP successfully contested while other parties that emerged include Renua, People's Democracy, Direct Democracy Ireland and National Citizens Movement (aligned as DDI/NCM), none of whom won seats in the GE 2016.

42. R. Hearne, The Irish water war, austerity and the "Risen people", op. cit.

43. Michael Edwards, "Civil society", The Encyclopedia of Informal Education, 2005, [www.infed.org/association/ civil_society.htm].

44. For example Social Justice Ireland, European Anti Poverty Movement, TASC (think tank for action on social change). 
are often radical but are rarely couched within a counter-hegemonic or anti-capitalistic frame ${ }^{45}$.

To better distinguish these spheres of civil society we adapt Wright's ${ }^{46}$ framework to distinguish the different traditions within which progressive civil society mobilises. Wright identifies three strategic logics of transformation that characterise the history of anti-capitalist struggle. Ruptural or revolutionary transformations envision a sharp break with existing institutions and social structures through direct confrontation. Interstitial transformations seek to build new forms of social empowerment in capitalist society's niches and margins that serve as both critique and evidence that alternative ways of working and living are possible. Symbiotic transformations involve strategies where the state and civil society simultaneously help to solve practical problems faced by dominant classes and elites through "non-reformist reforms", reforms that simultaneously make life better within the existing economic system. While some symbiotic reforms might also expand the potential for future advances of democratic power, other reformist agendas are parasitic in nature in that they prop up and ultimately reinforce the status quo.

Table 2 illustrates how these political traditions involve not only different relations with the state but also translate into different attitudes to interaction with political society. The state also shapes the context in which civil society operates and has structurally shifted in its power relations with civil society, both ceasing controversial social partnership arrangements and eroding broader civil participative networks. The 2015 UN ICESRC ${ }^{47}$ committee report to Ireland raised concern at the lack of meaningful consultation with civil society, and civil society seems relatively more eager to reconstruct methods of state/society dialogue than to engage in wider mobilisation for transformative political mobilisation ${ }^{48}$. The shifting role of trade unions is particularly important in this shift from social partnership to social dialogue. While some, including the largest trade union SIPTU, are eager for dialogue relations with the state, others, including Right2Water campaigning unions, have fostered an alternative approach focused on forms of mobi-

45. Jesuit Centre for Faith and Justice, "Protecting the Environment", Working Notes, $\mathrm{n}^{\circ} 72$, Dublin, Jesuit Centre for Faith and Justice, 2013, [http://www.workingnotes.ie/index.php/component/zoo/category/issue-72-protecting-the-environment? Itemid $=155]$.

46. Erik O. Wright, "Transforming Capitalism through Real Utopias”, American Sociological Review, vol. 78, n 1, 2013, p. 1-25.

47. Committee on Economic, Social and Cultural Rights, Concluding observations on the third periodic report of Ireland, E/C12/IRL/CO 3, Geneva, UN, 2015.

48. Paul Gillespie, "World View: The case for a new type of social partnership", Irish Times, 11 March 2016, [http://www.irishtimes.com/opinion/world-view-the-case-for-a-new-type-of-social-partnership-1.2569760]. Michael Clifford, "Godfather of social partnership believes it is time for its rebirth", Irish Examiner, 3 January 2015, [http://www.irishexaminer.com/viewpoints/analysis/godfather-of-social-partnership-believes-it-is-time-for-itsrebirth-305022.html]. 


\begin{tabular}{|c|c|c|c|c|c|}
\hline & Tradition & Pivotal actors & $\begin{array}{l}\text { Strategic logic with } \\
\text { respect to the state }\end{array}$ & $\begin{array}{c}\text { Strategic logic } \\
\text { with respect } \\
\text { to the capita- } \\
\text { list class }\end{array}$ & $\begin{array}{l}\text { Likely trajec- } \\
\text { tory }\end{array}$ \\
\hline Ruptural & $\begin{array}{l}\text { Revolutionary } \\
\text { socialist or com- } \\
\text { munist }\end{array}$ & $\begin{array}{l}\text { Classes in political } \\
\text { society (small and } \\
\text { factured) }\end{array}$ & $\begin{array}{l}\text { Oppositional protest } \\
\text { politics, unlikely to } \\
\text { enter government }\end{array}$ & Confrontation & $\begin{array}{l}\text { Continue in } \\
\text { small fractu- } \\
\text { red clusters } \\
\text { but some } \\
\text { growth }\end{array}$ \\
\hline Interstitial & Anarchist & $\begin{array}{l}\text { Less involved in } \\
\text { distributional and } \\
\text { status issues but } \\
\text { vibrant in ecolo- } \\
\text { gical, urban and } \\
\text { gender politics }\end{array}$ & Non state-oriented & Ignore & $\begin{array}{l}\text { Some creative } \\
\text { alliances with } \\
\text { both ruptural } \\
\text { and symbiotic }\end{array}$ \\
\hline $\begin{array}{l}\text { Symbiotic } \\
\text { Reformist }\end{array}$ & $\begin{array}{l}\text { Offensive Social } \\
\text { democratic }\end{array}$ & $\begin{array}{l}\text { Distributional, em- } \\
\text { ployment and status } \\
\text { issues, equality and } \\
\text { rights frames }\end{array}$ & $\begin{array}{l}\text { State-oriented, civil } \\
\text { and social dialogue }\end{array}$ & Engage & $\begin{array}{l}\text { Contribute } \\
\text { to narrative } \\
\text { of alterna- } \\
\text { tives but } \\
\text { in comfort } \\
\text { zone of social } \\
\text { dialogue }\end{array}$ \\
\hline $\begin{array}{l}\text { Symbiotic } \\
\text { Reinforcing }\end{array}$ & $\begin{array}{l}\text { Defensive Social } \\
\text { democratic }\end{array}$ & $\begin{array}{l}\text { Protecting vulne- } \\
\text { rable and often } \\
\text { focused on services } \\
\text { and life contin- } \\
\text { gencies }\end{array}$ & $\begin{array}{l}\text { State oriented, civil } \\
\text { and social dialogue }\end{array}$ & Collaborate & $\begin{array}{l}\text { Co-opted in } \\
\text { maintaining } \\
\text { status quo. }\end{array}$ \\
\hline
\end{tabular}

Table 2: Irish Civil Society - strategic logics (Source adapted from Wright (2013).

lisation and protest-oriented "politics". Many civil society NGOs identify as progressive and symbiotic. However, over the crisis, some may have shifted into more defensive and narrow instrumental campaigns ${ }^{49}$. This defensive political space is often characterised by a lack of solidarity and has potential to undermine more strategic narratives with longer term capacity to realise greater solidarity and more sustainable resistance to the overall neoliberal direction of the Irish state ${ }^{50}$. This lack of NGO leadership and solidarity also opens up a vacuum where those who seek more meaningful change must seek alternative civil or political leadership. In Europe this has raised conditions for populism.

We also need to be realistic about the strength of civil society as a source of alternatives. While there is a rich history of social movements in Ireland, recent scholarship suggests civil society has become more muted over the last decade as a

49. Mary P. Murphy, "Irish Civil Society: Rearranging the Deck Chairs on the Titanic? A Case Study of Fighting Irish Social Security Retrenchment", Journal of Civil Society, vol. 12, $\mathrm{n}^{\circ}$ 1, 2014, p. 1-16, [http://dx.doi.org/10 $.1080 / 17448689.2016 .1117244]$.

50. R. Hearne, The Irish water war, austerity and the "Risen people", op. cit. 
proactive state sought to co-opt civil society and shape its direction and diminish capacity for social transformation ${ }^{51}$. Various statutory initiatives have discouraged or prohibited the political capacity of civil society with legal mandates disallowing advocacy if an organization is in receipt of state funding ${ }^{52}$. This has had a "chilling effect" on many organisations and has clearly diminished civil society capacity to be socially transformative. This has had gendered impacts: austerity measures have heavily impacted on the organisation of feminist, and women's advocacy and support services ${ }^{53}$. Civil and political society is rendered weaker by the absence of women in both formal politics and broader public and media spheres, and by the tendency to restrict women to commenting on social but not economic affairs.

\section{圈 A new politics?}

In September 2015 Jeremy Corbyn was elected British Labour Party leader, while at the time of writing in April 2016, outsider Bernie Sanders continues his campaign for the United States Democratic Party presidential nomination. Both seek to promote a new politics giving voice to those who feel excluded. The experience of GE 2016 suggests Irish political and civil society is struggling to develop a new politics. What might we learn from elsewhere? Silva's ${ }^{54}$ analysis of building a social left in four Latin America countries (Argentina, Ecuador, Bolivia, and Venezuela) found that, while unions took the initial lead in mobilising against neoliberal reforms, wider society took the lead in the context of weakening of unions. Over several waves and decades of popular mobilisation around concrete issues, they built forms of collective power, eventually creating the conditions and the constituency for the emergence of strong new left governments and new politics. Crisis was used as opportunity to create and use political "space" and to build "alliances" across and between different sectoral interests, transnational ideas and networks were utilised to create broad domestic agendas to sustain alliances. Finally, through promoting practical pragmatic reformist agendas, advances were made and greater changes achieved. All this required a patient coalition-building over decades and waves of mobilisation. How have the Irish fared on coalitionbuilding across political and civil society and have they the patience for decades of mobilisation?

51. Brian Harvey, Government Funding and Social Justice Advocacy, Dublin, The Advocacy Initiative, 2014;Kieran Allen, "The model pupil who faked the test: Social policy in the Irish crisis", Critical Social Policy, vol. 32, n 3, 2012, p. 422-439.

52. Community Work Ireland, In Whose Interests, Galway, CWI, 2015.

53. Mary P. Murphy, "Gendering the narrative of the Irish Crisis", Irish Political Studies, vol. 32, 2015, p. 1-20.

54. Eduardo Silva, Challenging Neoliberalism in Latin America, Cambridge and New York, Cambridge University Press, 2009. 
Irish left parties generally do not have a strong track record of co-operation with civil society organizations. Ó Broin argues that they often treat NGOs and civil society as little more than a recruiting ground. Nonetheless, they overlap with civil society and how they choose to work and develop alliances will impact on civil society (and, of course, vice versa). Support for independents is interpreted as support for a new politics in Ireland; However, proliferation of independent candidates might also be an indicator of lack of motivation for and capacity to mobilise a new politics. Conditions trigger motivation for mobilisation. Neoliberalism has caused economic volatility in Ireland. However, despite unresolved high levels of individual and collective indebtedness, unemployment, emigration and increased deprivation, conditions do not compare to other European countries in crisis, nor does the extent of social disruption reach Latin American proportions. While the $2016 \mathrm{GE}$ showed the extent of anger and disillusionment of many, it may also be the case that the Irish crisis has not been grave enough to cause a reaction with sufficient force to provoke a change of course or a new politics. That said crisis is still alive in Irish society, and the potential for increased conflict remains. This is evident in the anti-water charges protest movement which echoes some of the approaches found in Latin America, both in terms of coalition building and issue framing. On the other hand, this movement is relatively narrow in its "frame" and so limited in its capacity to develop alliances. Motivation is also stimulated by extensive political exclusion and a crisis of representation, where citizens mistrust political institutions. Opinion polls and election results highlight the turbulence and volatility in Irish politics and it is unclear, at the time of writing, what politics will evolve over the next decade.

Silva emphasises the importance of associational power, or the formation of groups, and collective power, the formation of new coalitions or alliances, in achieving change. He argues that Latin American elite leaders tried to fragment different parts of civil society. This has echoes in Ireland where the elite tries to divide public and private and creates divisions between key groups of trade unions and NGOs ${ }^{55}$. Many trade unions and NGOs are sectoral and organised around specific campaigns to advance policy or row back individual austerity measures. They are also conditioned by a consensus relationship with the state. Government has implemented rollbacks in some cuts that, while not significant in terms of percentage of GDP, are politically significant in encouraging groups to persist in sectoral campaigns and justify resistance to the harder and riskier work of coalition building. At the same time there is some evidence of the type of collective mobilisation that happened in Latin America. Various types of attempts to link across sectors can be found in various grassroot gatherings, such as Clai-

55. K. Allen, "The model pupil who faked the test: Social policy in the Irish crisis", art. cit. 
ming Our Future, We're Not Leaving, and various campaigns against precarity. Right2Water also demonstrates significant capacity for protest and collective action. These efforts have not yet created the conditions for a significant "new politics"; elsewhere indeed, this took decades. There also appears to be a shift in culture in protest and electoral politics. Old cultures are eroded by the decline in trade union membership and civil society. New cultures of communication have emerged through social media and organisations like Uplift and the street protest culture of the small but revived and energetic Trotskyite left $^{56}$ and of the Irish presence in the global Occupy movement. The challenge is to recognise the fragmented, complex and diverse nature of social politics and the public sphere and to mobilise across this complexity.

There is some optimism that the development of a national conversation about credible alternatives evident in the Right2Change campaign and among various oppositional movements has achieved some critical mass in the context of wider dissatisfaction with austerity and the political elite ${ }^{57}$. This builds on work by think tanks NERI and TASC and from contributions from civil society including the National Women's Council, the European Anti-Poverty Network and Community Platform and is consistent with earlier attempts to build alternative budget frames by Claiming our Future in Plan B campaigns in 2011 and 2012. The question is whether any can develop sufficient momentum, resilience and persistence to last the time needed to develop broader alliances.

Silva emphasises ideological power and the need to frame messages and narratives with a view to brokering new linkages. Unger describes the challenge of creating a high-energy democracy and raising the temperature of politics ${ }^{58}$. To date there has not been effective framing in the various Irish protests. Issues have not been framed in a manner that might unite a critical mass around a positive vision of alternatives that can inspire or motivate united action to create a world without the social, democratic, cultural and economic damage associated with neoliberalism. Silva advises that such a framing is crucial to brokering the linkages necessary to achieve change. A new politics requires a "new policy consensus". In Latin America that new consensus reaffirmed the legitimacy of state involvement in the economy and society; an ecologically driven model of development; less reliance on and greater regulation of markets; less reliance on foreign investment; and more social investment in welfare, health, education, and pensions as well as a focus on inclusion and equality of status for all, including women. Such an Irish narrative could create new solidarities based on an understanding of our collective

56. Dan Finn, “A Second Republic”, New Left Review Seminar, Central Hotel Dublin, 25 June 2015.

57. Eoin Ó Broin (2015), op. cit., p. 15.

58. Roberto Unger, "The Future of the Left", The European, 24 October 2011, p. 1-5. 
interdependence. More, and more effective, protest could emerge on foot of this new politics.

New tactics and new types of civil society linkages and new alliances between civil society and political society are crucial to fill the vacuum or "void" in democratic left politics described earlier ${ }^{59}$. New ideas are also crucial and need to be bigger and bolder than ideas recently promoted in the context of New Left Review sponsored debate on a "second republic" (the defence of the traditional European model of social democracy ${ }^{60}$, or a national project to eliminate child poverty ${ }^{61}$ ). Fraser $^{62}$ draws our attention to the need for a conceptual framework that offers a way to interpret the crisis in ways that unite us and allow us to find a new emancipatory way to build a new narrative and create new political solidarities. She argues for "a triple movement" against the "self-regulating market" that commodifies nature, labour and money and in contemporary terms creates new markets in ecology (carbon emissions and biotechnology), in care and social reproduction (child-care, schooling, and care of the old), and in money (financial derivatives and speculation). Linkages can be made across the triple crisis of "capitalism, social reproduction and the environment". A second republic requires a strong vision and narrative. An Irish triple movement which incorporates gender and social reproduction, environmental and traditional distributional concerns about income equality and public services could inspire a new politics. This framing offers potential to mobilise across a wide range of actors, enables people to see what unites them rather than what divides them, and increases the likelihood of a lively battleground in which the interests of a much wider section of the population can find expression, create new alliances and reshape power relations.

59. Peter Mair, Ruling the Void, London, Verso, 2015.

60. D. Finn, "A Second Republic", art. cit.

61. Fintan O’Toole, "A Second Republic”, New Left Review Seminar, Central Hotel Dublin, 25 June 2015.

62. Nancy Fraser, "A Triple Movement? Parsing the Politics of Crisis after Polanyi”, New Left Review, n 81, 2013, p. 119-132. 